Original Research

\title{
UJI AKTIVITAS ANTIBAKTERI SABUN CAIR EKSTRAK ETANOL 70\% DAUN SIRSAK (Annona muricata L) TERHADAP BAKTERI Staphylococcus aureus
}

\section{ANTIBACTERIAL ACTIVITY TEST FOR LIQUID SOAP 70\% ETHANOL EXTRACT SOURSOP LEAF (Annona muricata L) LEAVES AGAINST Staphylococcus aureus}

\author{
Tia Fuji Lestari ${ }^{l}$, Sutriningsih ${ }^{2} *$ \\ Fakultas Farmasi, Universitas 17 Agustus 1945 Jakarta, Jakarta Utara, Indonesia, 14350 \\ *E-mail: vinnelaras@yahoo.co.id \\ Diterima: $12 / 10 / 2019$ \\ Direvisi: 04/11/2019 \\ Disetujui: 16/03/2020
}

\begin{abstract}
Abstrak
Keadaan dimana masuknya mikroorganisme kedalam tubuh, berkembang biak dan menimbulkan penyakit disebut dengan infeksi. Infeksi terjadi jika salah satu organisme hidup serta merugikan organisme lain yaitu inangnya, salah satunya disebabkan oleh bakteri Staphylococcus aureus. Tanaman yang dapat dimanfaatkan sebagai obat tradisional antara lain Daun Sirsak (Annona muricata L) atau lebih dikenal dengan nama sirsak. Kegunaannya sebagai obat tradisional yaitu sebagai antibakteri, antiparasit, antivirus, obat cacing, dan dekongestan Daun sirsak sendiri mengandung senyawa saponin, flavonoid, tanin, dan alkaloid yang mempunyai fungsi sebagai antiseptikdesinfektan, sehingga tanaman ini dapat digunakan sebagai antibakteri. Tujuan penelitian ini untuk mengetahui apakah sabun cair ekstrak etanol $70 \%$ daun sirsak (Annona muricata L) memiliki sifat sebagai antibakteri.Pembuatan ekstrak dilakukan dengan metode maserasi dengan etanol 70\%. Ekstrak di formulasikan menjadi sediaan sabun cair dengan konsentrasi 6,25\%, 12,5\%, dan 25\%. Dan dievaluasi organoleptik, pH, Homogenitas kemudian dilanjutkan dengan uji aktivitas antibakteri. Hasil uji aktivitas sabun cair ekstrak daun sirsak menunjukan diameter hambat $6,25 \%, 12,5 \%$ dan $25 \%$ masing-masing $27,56 \mathrm{~mm}, 28,17 \mathrm{~mm}$ dan $30,87 \mathrm{~mm}$. Berdasarkan hasil uji yang diperoleh maka dapat disimpulkan bahwa sabun cair ekstrak daun sirsak (Annona muricata L) dapat dibuat menjadi sediaan sabun cair dan memiliki daya hambat terhadap bakteri Staphylococcus aureus.
\end{abstract}

Kata kunci:Daun Sirsak (Annona muricata L), Antibakteri, Staphylococcus aureus, Sabun Cair

\begin{abstract}
The situation in which the entry of microorganisms into the body, multiply and cause disease is called an infection. Infection occurs if one organism lives and harms another organism, namely its host, one of which is caused by the bacterium Staphylococcus aureus. Plants that can be used as traditional medicine include Soursop Leaves (Annona muricata L) or better known as soursop. Its usefulness as traditional medicine is as an antibacterial, antiparasitic, antiviral, anthelmintic, and decongestant Soursop leaves themselves contain compounds saponins, flavonoids, tannins, and alkaloids which have functions as antiseptic-disinfectants, so this plant can be used as an antibacterial. The purpose of this study was to determine whether $70 \%$ ethanol extract soursop (Annona muricata L) ethanol extract liquid soap has antibacterial properties. Extracts were made using maceration method with $70 \%$ ethanol. The extract was formulated into liquid soap preparations with concentrations of $6.25 \%, 12.5 \%$, and $25 \%$ And evaluated organoleptic, $\mathrm{pH}$, homogeneity then continued with antibacterial activity test. The results of the liquid soap extract
\end{abstract}


test of soursop leaf extract showed inhibition diameters of $6.25 \%, 12.5 \%$ and $25 \%$ respectively $27.56 \mathrm{~mm}, 28.17 \mathrm{~mm}$ and $30.87 \mathrm{~mm}$. Based on the test results obtained it can be concluded that the liquid soap extract of soursop leaves (Annona muricata L) can be made into liquid soap preparations and has inhibitory properties against Staphylococcus aureus bacteria.

Keywords:Soursop Leaf (Annona muricata L), Antibacterial, Staphylococcus aureus, Liquid Soap

\section{PENDAHULUAN}

Kulit adalah pembungkus serta pelindung tubuh yang tahan terhadap air, dapat mengatur suhu tubuh serta mengandung berbagai ujung syaraf [1]. Kulit berisikan mikroorganisme yang bersifat sementara, contohnya bakteri Staphylococcus aureus yang merupakan bagian terbesar dari flora normal manusia serta termasuk dari spesies yang bersifat patogen. Bakteri tersebut dapat menyebabkan berbagai penyakit seperti jerawat dan bisul [2].

Tanaman yang dapat dimanfaatkan sebagai obat tradisional antara lain Daun Sirsak (Annona muricataL) atau lebih dikenal dengan nama sirsak. Kegunaannya sebagai obat tradisional yaitu sebagai antibakteri, antiparasit, antivirus,obat cacing, dan dekongestan [3].

Daun sirsak sendiri mengandung senyawa saponin, flavonoid, tanin, dan alkaloid yang mempunyai fungsi sebagai antiseptik-desinfektan, sehingga tanaman ini dapat digunakan sebagai antibakteri [4].

Senyawa flavonoid merupakan metabolit sekunder yang terdapat pada tumbuhan. Senyawa ini dapat digunakan sebagai obat infeksi pada luka, antitumor, antijamur, antimikroba, antikanker sertaantivirus. Selain itu flavonoid dapat digunakan sebagai anti bakteri, antialergi, sitotoksik, dan anti hipertensi [5].

Bakteri Staphylococcus aureus adalah bakteri Gram positif. Bentuknya seperti anggur serta dapat ditemukan di bagian selaput hidung, kulit, dan kantung rambut. Selain itu bakteriini dapat menyebabkan keracunan makanan serta infeksi kulit ringan hingga berat [6].

Sabun merupakan produk yang dapat digunakan untuk membersihkan diri dalam kehidupan sehari-hari dan merupakan bagian terpenting dalam kehidupan manusia. Sabun sendiri mempunyai kegunaan seperti mengobati penyakit, contohnya penyakit kulit yang disebabkan oleh bakteri dan jamur.

Sabun yang beradar dipasaran sangat bermacam-macam, terlihat dari warna, jenis, manfaat dan wangi yang ditawarkan. Salah satu jenis sabun yang sangat banyak diproduksi karena penggunaanya lebih praktis dan bentuk yang menarik yaitu sabun cair. Kelebihan sabun cair sendiri dibandingkan dengan sabun padat yaitu mudah dibawa, mudah disimpan, tidak mudah rusak atau kotor, serta penampilan kemasan yang menarik [7].

Berdasarkan hal tersebut, peneliti ingin membuat sediaan sabun cair ekstrak etanol $70 \%$ daun sirsak Annona muricata L dan menguji aktivitas antibakterinya pada berbagai konsentrasi terhadap bakteri Staphylococcus aureus.

\section{METODE}

\section{Bahan}

Bahan yang digunakan adalah Daun sirsak (Annona muricata L) berupa simplisia kering yang diperoleh dari BALITRO-Bogor, Etanol 70\% (Brataco), Kalium Hidroksida (Brataco), Natrium Methil Selulosa (Brataco), Asam Stearat (Brataco), Butil Hidroksi Toluen (Brataco), Aquadest, Minyak kelapa (Brataco), Sabun Cair Dettol, $\mathrm{NaCl}$ 0,9\%, HCl 0,1N, Mc. Farland 0,5, 
Bakteri Staphylococcus aureus ATCC 25923 yang diperoleh dari Laboratorium Fakultas Kedokteran Departemen Mikrobiologi Universitas Indonesia.

\section{PROSEDUR KERJA}

\section{Pembuatan Ekstrak}

Pembuatan ekstrak Daun Sirsak yaitu timbang sebanyak 1000 g daun sirsak, kemudian tambahkan $3000 \mathrm{ml}$ etanol, didiamkan \pm 24 jam, dipisahkan maserat dengan cara disaring. Kemudian dilakukan pengulangan dengan pelarut yang sama. Lalu kumpulkan semua maserat dan lakukan penguapan dengan vacuum rotary evaporator.

\section{Pembuatan Sabun Cair Ekstrak Daun Sirsak}

Timbang minyak kelapa sebanyak 30 g lalu masukan ke dalam beker glass kemudian tambahkan kalium hidroksida $40 \%$ sebanyak $16 \mathrm{ml}$ sedikit demi sedikit sambil terus di panaskan pada suhu $50^{\circ} \mathrm{C}$ hingga terbentuk pasta. Setelah itu tambahkan dengan $25 \mathrm{ml}$ aquadest dan natrium karboksi metil selulosa yang telah dikembangkan terlebih dahulu dengan aquadest panas lalu aduk ad homogen. Kemudian tambahkan asam stearat aduk homogen. Lalu tambahkan butil hidroksi toluen aduk ad homogen. Lalu yang terakhir ditambahkan ekstrak daun sirsak aduk sampai homogen.

\section{Uji Aktivitas Antibakteri}

Uji aktivitas antibakteri dari ekstrak daun sirsak (Annona muricataL) dilakukan dengan cara difusicakram. Dimana kertas cakram yang digunakan memiliki diameter $6 \mathrm{~mm}$. Caranya yaitu siapkan iltrate bakteri dalam larutan $\mathrm{NaCl}$, kekeruhan di standarisasi dengan konsentrasi Mc. Farland 0,5. Lalu iltrate tersebut diambil dengan swab steril kemudian digoreskan pada media agar secara merata. Diamkan plat kultur selama 5 menit, kemudian kertas cakram steril ditetesi masing-masing konsentrasi yaitu 6,25\%, 12,5\%, dan 25\% lalu didiamkan selama 30 menit agar menyerap ke cakram dan diletakan diatas permukaan agar. Untuk iltrat iltrate kertas cakram ditetesi aquadest. Untuk iltrat positif kertas cakram ditetesi sabun cair iltra. Kemudian masing-masing cawan petri diinkubasi selama 1 x 24 jam pada suhu $37^{\circ} \mathrm{C}$. Lalu aktivitas antibakteri diamati keesokan harinya berdasarkan diameter zona hambat atau daerah bening yang terbentuk di sekeliling kertas cakram tersebut. Kemudian pengukuran zona hambat menggunakan jangka sorong. Pengujian dilakukan 3 kali pengulangan.

\section{HASIL DAN PEMBAHASAN}

\section{Ekstraksi Daun Sirsak}

Sebanyak $1 \mathrm{~kg}$ daun sirsak (Annona muricataL) yang telah di haluskan menjadi serbuk halus di ekstraksi dengan menggunakan pelarut etanol $70 \%$ dengan menggunakan metode maserasi. Etanol adalah senyawa yang dapat menarik senyawapolar, non polar dan semipolar (Febriani, 2004). Lalu iltrate yang dihasilkan akan dipekatkan dengan vaccum rotary evaporator sehingga didapat ekstrak kental sebanyak 112,3 gram. 


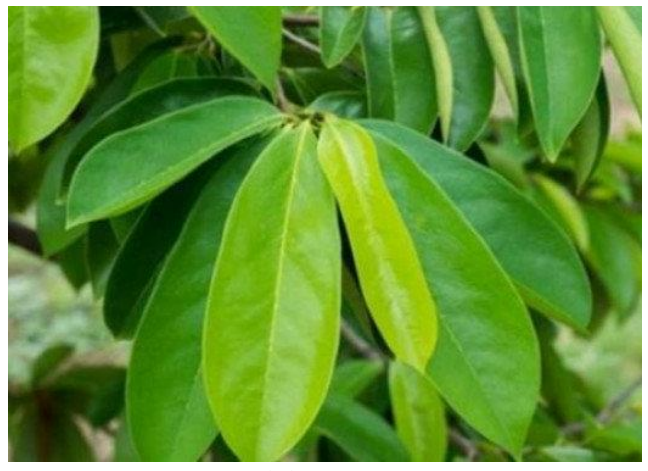

(a)

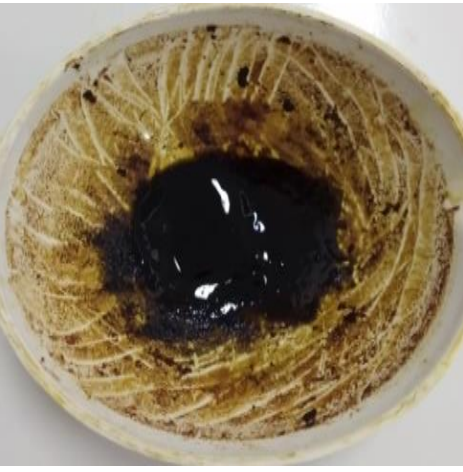

(b)

Gambar 1. Daun Sirsak (a) dan Ekstrak Daun Sirsak (b)

Hasil Uji Evaluasi Sabun Cair Ekstrak Daun Sirsak

Hasil Uji Organoleptis

Tabel 1. Hasil Uji Organoleptis

\begin{tabular}{|c|c|c|c|c|c|}
\hline \multirow{2}{*}{\multicolumn{2}{|c|}{ Pengujian }} & \multicolumn{4}{|c|}{ Suhu Kamar (minggu) } \\
\hline & & 1 & 2 & 3 & 4 \\
\hline \multirow[t]{3}{*}{ F1 } & Warna & $\begin{array}{c}\text { Hijau } \\
\text { Kecoklatan }\end{array}$ & $\begin{array}{c}\text { Hijau } \\
\text { Kecoklatan }\end{array}$ & $\begin{array}{c}\text { Hijau } \\
\text { Kecoklatan }\end{array}$ & $\begin{array}{c}\text { Hijau } \\
\text { Kecoklatan }\end{array}$ \\
\hline & Bau & Aromatik & Aromatik & Aromatik & Aromatik \\
\hline & Bentuk & Cair & Cair & Cair & Cair \\
\hline \multirow[t]{3}{*}{$\mathrm{F} 2$} & Warna & $\begin{array}{c}\text { Hijau } \\
\text { Kecoklatan }\end{array}$ & $\begin{array}{c}\text { Hijau } \\
\text { Kecoklatan }\end{array}$ & $\begin{array}{c}\text { Hijau } \\
\text { Kecoklatan }\end{array}$ & $\begin{array}{c}\text { Hijau } \\
\text { Kecoklatan }\end{array}$ \\
\hline & Bau & Aromatik & Aromatik & Aromatik & Aromatik \\
\hline & Bentuk & Cair & Cair & Cair & Cair \\
\hline \multirow[t]{3}{*}{ F3 } & Warna & $\begin{array}{c}\text { Hijau } \\
\text { Kecoklatan }\end{array}$ & $\begin{array}{c}\text { Hijau } \\
\text { Kecoklatan }\end{array}$ & $\begin{array}{c}\text { Hijau } \\
\text { Kecoklatan }\end{array}$ & $\begin{array}{c}\text { Hijau } \\
\text { Kecoklatan }\end{array}$ \\
\hline & $\mathrm{Bau}$ & Aromatik & Aromatik & Aromatik & Aromatik \\
\hline & Bentuk & Cair & Cair & Cair & Cair \\
\hline
\end{tabular}

Pada pengujian organoleptis sediaan sabun cair diamati secara visual dengan mengamati warna, bau, tekstur sediaan yang dibuat dengan variasi konsentrasi 6,25\%, 12,5\%, 25\%. Sabun cair ekstrak daun sirsak yang berwarna hijau kecoklatan dan bau khas aromatik. Hasil pengamatan tekstur sabun cair ekstrak daun sirsak yaitu cair. Tidak terjadi perubahan warna, bau maupun tekstur sabun cair setelah penyimpanan 4 minggu. Hal ini menandakan sabun cair bersifat stabil pada penyimpanan suhu kamar. 


\section{Hasil Uji Homogenitas}

Pada pengujian homogenitas bertujuan untuk melihat bahan-bahan dari sediaan sabun cair tercampur dan tersebar merata antara zat adiktif dan basis sabun cair menjadi homogen. Sabun cair yang homogen ditandai dengan tidak terdapatnya gumpalan/butiran kasar. Berdasarkan hasil pemeriksaan menunjukkan sediaan sabun cair ekstrak daun sirsak dengan konsentrasi 6,25\%, $12,5 \%, 25 \%$ tidak memperlihatkan adanya butiran kasar atau gumpalan saat sabun cair dioleskan pada kaca objek.

Tabel 2. Hasil Uji Homogenitas

\begin{tabular}{|c|c|}
\hline Jenis Sabun Cair & Homogenitas \\
\hline Kontrol Negatif & Homogen \\
\hline Kontrol Positif & Homogen \\
\hline F1 6,25\% & Homogen \\
\hline F2 12,5\% & Homogen \\
\hline F3 25\% & Homogen \\
\hline
\end{tabular}

\section{Hasil Uji Aktivitas Antibakteri}

Ekstrak etanol 70\% Daun Sirsak (Annona muricataL) diformulasikan menjadi sediaan sabun cair, karena bentuk sediaan yang mudah digunakan, mudah dibawa, mudah dibersihkan, sebagaipembersih dan pelindung kulit. Formulasi ekstrak etanol 70\% (Annona muricataL) dibuat dengan tiga konsentrasi yaitu 6,25\%, 12,5\% dan 25\%. Lalu dilakukan pengujian antibakteri dengan menggunakan metode difusicakram, caranya dengan menempelkan kertas cakram yang telah dibasahi dengan ekstrak dan sediaan sabun cair dalam mediaMueller Hinton Agar (MHA) yang telah di swab dengan bakteriStaphylococcus aureus. Sebagai kontrol positif digunakan sabun cair dettol dan kontrol negatif menggunakan aquadest. Ujiini dilakukan untuk mengetahui besar diameter daya hambat yaitu daerah bening di sekitar blank disk yang menunjukan adanyapertumbuhan bakteriStaphylococcus aureus.

Tabel 3. Hasil Uji Aktivitas Antibakteri

\begin{tabular}{|c|c|}
\hline Perlakuan & Rata-rata diameter zona hambat (mm) \\
\hline Positif & 21,43 \\
\hline Negatif & 0 \\
\hline F1 6,25\% & 10,58 \\
\hline F2 12,5\% & 14,16 \\
\hline F3 25\% & 15,92 \\
\hline
\end{tabular}


Dari hasil ujiaktivitas antibakteri sabun cair ekstrak daun sirsak (Annona muricataL) terhadap BakteriStaphylococcus aureus menunjukan adanyaperbedaan maknaantara kelompok kontrol positif dengan semua kelompok perlakuan. Dimanapada kontrol positif memiliki diameter rata-rata 21,43mm. Munculnya zona hambat ini disebabkan karena kontrol positif yang digunakan adalah sabun cair dettol. Sedangkan pada kontrol negatif tidak menunjukan adanya zona hambat karena menggunakan aquadest yang tidak terdapat zat aktif sebagaiantibakteri. Pada sabun cair ekstrak daun sirsak yang dilakukan 3x pengulangan pada konsentrasi 6,25\%, 12,5\%, dan $25 \%$ menunjukan adanya zona bening di sekitar cakram, pada konsentrasi $25 \%$ memiliki rata-rata diameter yaitu $15,92 \mathrm{~mm}$, pada konsentrasi $12,5 \%$ memiliki rata-rata diameter yaitu $14,16 \mathrm{~mm}$ sedangkan pada konsentrasi $6,25 \%$ memiliki diameter rata-rata yaitu $10,58 \mathrm{~mm}$.

Timbulnya diameter zona hambat tersebut karenaadanya senyawa di dalam daun sirsak yang memiliki sifat sebagaiantibakteri yaitu sepertialkaloid, saponin, tanin, steroid, glikosida dan flavonoid.

\section{Analisa Data}

Data dianalisis menggunakan SPSS versi 22. Data yang diperoleh adalah diameter daya hambat disekitar cakram dilakukan uji normalitas dan uji homogenitas. Syarat data terdistribusi normal dan homogen yaitu jika nilai sig $>0,05$. Lalu jika data memenuhi syarat uji normalitas dan uji homogenitas sehingga data dapat dianalisa dengan menggunakan One Way ANOVA data harus memenuhi distribusi normal dan homogen. Tujuan dilakukan uji ANOVA adalah untuk melihat perbedaan yang signifikan antar tiap perlakuan dalam menghambat pertumbuhan bakteri [8]

Uji normalitas yang diperoleh menunjukan kontrol positif nilai sig 0,888 , konsentrasi $25 \%$ nilai sig 0,819 , konsentrasi $12,5 \%$ nilai sig 0,995 , dan konsentrasi $6,25 \%$ nilai sig 0,084 . Dari data tersebut memperoleh nilai signifikan $>0,05$, maka Ho diterima atau data terdistribusi normal seperti. Uji homogenitas menunjukan sig 0,357. Dari data tersebut memperoleh nilai> 0.05, maka varian data yaitu sama atau homogen. Berdasarkan analisa data yang diperoleh dari hasil uji statistik, aktivitas antibakteri sabun cair ekstrak daun sirsak (Annona muricataL) terhadap Bakteri Staphylococcus aureus didapatkan data yang normal dan homogen dengan taraf kepercayaan 95\%, sehingga dapat di lanjutkan dengan menggunakan ujiOne Way ANOVA. Dari data uji ANOVA yang didapat menunjukan nilai sig 0,000 $(<0,05)$, maka Ho ditolak yaitu artinya terdapat perbedaan yang signifikan antar tiap-tiap formulasi dalam menghambat pertumbuhan bakteri [8].

Karena adanya perbedaan pada data yang dimiliki maka dapat dilakukan uji lanjutan yaitu ujiPost Hoc. Ujiini menggunakan metode Last Significant Different (LSD) untuk melihat perbedaan signifikan di setiap kelompok perlakuan. Dari data menunjukan perbandingan antar perlakuan dalam menghambat pertumbuhan bakteri dengan melihat nilai sig yang diperoleh. Konsentrasi 25\% memiliki daya hambat yang besar daripada konsentrasi yang lainnya dengan melihat Nilai Mean Difference namun tidak terdapat perbedaan yang signifikan antara 25\% dengan $12,5 \%$ dan nilai sig yang diperoleh yaitu $0.095(>0,005)$ maka Ho diterima karena tidak terdapat perbedan yang signifikan [8]. 


\section{KESIMPULAN}

Ekstrak Daun Sirsak yang saya uji dan saya teliti terhadap bakteri Staphylococcus aureus memiliki aktivitas sebagai antibakteri dan Sabun cair ekstrak daun sirsak (Annona muricataL) yang saya teliti dan uji mempunyai daya hambat paling besar pada konsentrasi $25 \%$ dibandingkan dengan konsentrasi $12,5 \%$ dan $6,25 \%$.

\section{DAFTAR PUSTAKA}

1. Gardner, Gray, O’rahilly. Anatomi, Penerbit Universitas Indonesia, Jakarta.1995.

2. Jawetc, et al. Mikrobiologi Kedokteran. Jilid 1. ed. Buku Kedokteran EGC, Jakarta. 2005.

3. Anonim, Graviola :http://www.rain-tree.com/Graviola-Monograph.pdf. 2007.

4. Hutapea, J.R., Inventaris Tanaman Obat Indonesia. Beda Penelitian Dan Pengembangan Kesehatan, Departemen Kesehatan Republik Indonesia, Jakarta. 1993.

5. Sriningsih. Analisa Senyawa Golongan Flavonoid Herba Tempuyung (SonchusarvensisL). 2008.

6. Staf Pengajar FKUI. Buku Ajar Mikrobiologi Kedokteran Edisi Revisi. Jakarta:Binarupa Aksara. 1994.

7. Widyasanti, Asri dkk. Pembuatan Sabun Cair Berbasis Virgin Coconut Oil (VCO) Dengan Penambahan Minyak Melati (Jasminum Sambac) Sebagai Essential Oil, Sumedang. 2014.

8. Priyatno, D. Panduan Praktis Olah Data Menggunakan SPSS. Yogyakarta: ANDI. 2017. 